\title{
豊橋ハリストス正教会の聖堂建築の研究
}

最近発見・発刊された資料による建設経緯と設計の分析

\section{A STUDY ON TOYOHASHI KHRISTOS ORTHODOX CHURCH}

Analysis of construction process and planning through lately found and published records

\author{
泉田英雄*, 伊藤晴康 ${ }^{* *}$, 西澤泰彦*** \\ Hideo IZUMIDA, Haruyasu ITO and Yasuhiko NISHIZAWA
}

\begin{abstract}
Toyohashi Khristos Church was dedicated to Matthew the Evangelist in 1915 with design of Izo Kawamura, a priest in charge of the sacred property management. Through the Overall Survey of Modernization Heritages in Aichi Prefecture took place in 2003-2005, primary sources including the original building drawings and photographs were found. And using these references, it will be possible to analyse how Kawamura prepared the plans and executed the construction supervision in cooperation with local believers. Referring to the model plan provided by St. Nikolai and the existing churches at Kyoto and Osaka, Kawamura found the principle of the layout and the proportion. An important instrument was a pair of large compasses to draw a circles and diagonals. As the site did not have enough length, and the size calculated by the principle had fractions, Kawamura had to adjust the ideal church plan to the site condition. His unique interpretation and originality were reflected in slightly decreasing tiered bell tower like Buddhist tower. Through his careful supervision stationing at the site quite long time, such adjustment could be possible.
\end{abstract}

Keywords: Russian Orthodox Church, Church Architecture, Building Construction, Izo Kawamura ロシア正教会, 近代建築、教会建築, 建築構造, 河村伊蔵

\section{1. はじめに}

豊橋ハリストス正教会・聖使徒福音者馬太聖堂は大正4(1915)年に 成聖し、幸運にも第二次世界大戦時の空襲にあわず、今日まで優雅 なその姿をみせている。2003年から2005年に行われた愛知県近代化 遺産総合調查 ${ }^{1)}$ の過程において、信徒の方から新たな資料が提供さ れ、また部分修理のために内部を視察調査する機会があり、さらに 故内井昭蔵氏の遺族から河村伊蔵に関する資料が寄せられ、2007年 度にこれらをもとにして豊橋市教育委員会は本聖堂建築の本格的調 查を実施した。飯田喜四郎明治村館長を顧問に、表記三人がその調 查を実施し2)、その成果は2008年6月の重要文化財指定へと結実し た。本稿の目的はこれら資料をもとに豊橋聖堂の設計と建設の過程 を整理し、その建築的特徵を分析するものである。

ハリストス正教会の建築に関しては、1960年代、元東北大学教授 の坂田泉氏と佐藤巧氏が近代建築研究の一環として先駆的研究を 行った ${ }^{3)}$ 。『日本正教会伝導誌』などの限られた二次記録を整理する ことにより、日本における正教会建築を概観し、さらに石巻や仙台 の聖堂について若干の考察を加えた。岩手県から宮城県を流れる北 上川流域には、20棟を越える大小さまざまな木造教会が建設された が、第二次世界大戦で仙台聖堂は焼失し、また終戦後、信徒数が減 少したことで関係資料の多くが紛失、散冕してしまった。宮城県以
外に範囲を広げれば、『正教時報』や成聖記念誌などの二次記録を 資料に用いて各地の聖堂の建設経緯や形態を知ることは可能であ り、1970年代末に鈴木甲子男氏がそれを実施した4)。また、個別の調 查として、ニコライ堂 (東京復活大聖堂) は近代東京を代表する建築 の一つであり、またジョサイヤ・コンドルが実施設計に、岡田信一 郎が再建に関わったことから、詳細な建築史研究が行われた5)。ニコ ライ堂以外では、京都聖堂と小田原・箱根教会ではその文化財指定 のために簡単な建築調查が行われ に際して詳細な報告書が作成されている7)。

これらの既往研究では、建物の設計や建設に直接関連する一次記 録(関係者の記録や設計図など)はほとんど用いられてこなかった が、最近『宣教師ニコライの全日記』 ${ }^{8)}$ が邦訳出版され、これを資料 として新たな研究も展開されるようになった9)。豊橋正教会の場合、 教会日誌 ${ }^{10)}$ や設計図書が残され、これらを資料に用いることによっ て実際の設計と建設過程を分析することができ、日本近代建築史に 新たな知見を提供することになろう。

2. 豊橋以前の聖堂 : 箱館、石巻、東京、仙台、京都、松山、大阪 豊橋聖堂建設に至る道筋を、既往研究の成果を最近の発見・発刊 された資料に付き合わせて整理する。安政の修好通商条約にもとづ

\footnotetext{
* 豊橋技術科学大学 准教授 ·博士 (工学) 
き幕末日本に外国人居留地が開かれ、そこに再びキリスト教徒が居 住することになった。条約締結国の一つのロシアは政教一致の国で あり、箱館に自国民の保護のために領事と、また結婚や出産などの 届出と儀礼のために司祭を置いた。箱館の最初のロシア領事館は実 行寺を仮止泊所として利用していたが、安政6 (1859) 年に大工町 (現 元町)の土地を奉行から借り受け、翌年ここに領事館建物と礼拝堂を 完成させた ${ }^{11)}$ 。これが日本最初の正教会聖堂建築であった。領事館 付司祭としてマアホフが就任したが、翌年病気のために帰国し、文 久元 (1861) 年、ニコライが後任として着任し、その後約半世紀近く にわたり日本でのロシア正教会の活動を指揮することになる。

日本人にとっていまだキリスト教は禁令であったが、箱館で数人 の有力日本人信徒を得ると、明治5(1872) 年、ニコライは本州太平洋 沿岸を南下し、日本の中心である東京へ向かった。神田町駿河台に 土地を求め、そこに東京礼择堂他を建設し、キリスト教布教が許可 される日を待った。その日は明治6(1873) 年に訪れ、有力信徒のいた 宮城県北部や愛知県東部などの沿岸地方で大きな成果をあげた。二 コライは地域信徒の箱船となる聖堂の建設を支援し、宮城県北部で はいち早く実現した。石巻聖堂は明治13(1880) 年に完成し12)、同じ 規模と形態で涌谷や佐沼などにつぎつぎ聖堂が建てられた。石巻聖 堂は 1 階に集会所、2 階に礼拝所を置く和洋折褁の総 2 階木造建築 で、市指定文化財として移築復元されている。明治18(1885) 年、 12,000人余りの信徒を数えるまでになったが、その他の地方教会で は建設資金を集めるのが難しく、既存の建物を再利用し礼洋所とし た。

1880年、ニコライは主教に昇叙されると、日本の首都である東京 にふさわしい大教会を建てたいと強く望むようになった。一時帰国 した際、その聖堂設計にふさわしい建築家を探し、結局ミハイル . アレフィエヴィッチ・シチュールポフに委託した ${ }^{13)}$ 。榛施設計と設 計監理は当時工部大学校教授であったジョサイヤ・コンドルが担 い、総請負は信者の長郷泰輔が行い、また信徒大工数人が参加した ことが知られている ${ }^{14)}$ 。これ 7 年の工期を要して完成し、東京復活 大聖堂として1891年(明治24) 3 月に成聖式が執り行われた。

東京大聖堂の成聖式には全国から司祭と有力信徒が集まり、そこ で彼らは初めて西洋式の大聖堂を目にした。彼らはその姿に圧倒さ れ、地元にも本格的な聖堂建築を建てたいと希求するようになっ た。ニコライもそれを支援し、信徒大工を参考図を持たせて打ち合 わせに派遣し、明治25(1892) 年7月に秋田の曲田教会 (現北鹿教会)、 また同年12月に仙台教会の聖堂が成聖した ${ }^{15)}$ 。両者は玄関、啓蒙 所、聖所、至聖所が一直線に並ぶという平面構成は共通するが、規 模や外観など多くの点で異なっていた。

仙台に引き続き、ニコライは京都にも聖堂を建てることを決心

し、明治35 (1902) 年、京都在住信徒を通して府建築技師の松室重光 に面会し、参考図を示して実施設計を依頼した ${ }^{16)}$ 。京都聖堂は明治 36 (1903) 年5月10日に成聖し、その前日に河村伊蔵が聖器物の備え付 けを行った。大阪にも同様の聖堂の建設を目指したが、日露戦争勃 発のために延期しなければならなかった。日露戦争終結後、ロシア 人篤志家からの莫大な寄付により、最も多くの捕虜が収容された松 山に記念聖堂が建てられ ${ }^{17)}$ 、また大阪聖堂の建設が再開された ${ }^{18)}$ 。 どちらもニコライから渡された図譜をもとに河村が実施設計から施 工監理までを行い、東京大聖堂と京都聖堂では外部建築家に委託さ
れたが、日露戦争以後は聖職者河村伊蔵が専ら担うようになってい た。また、東京大聖堂竣工以後は、それ以上大規模な建設事業はな かった。

\section{3. 河村伊蔵について}

豊橋、函館、白河、修善寺などの聖堂は河村の設計であることは 知られていたが、どのような人物であったのか長い間不明であった 19)。一方、研究者の立場ではなく故内井昭蔵氏が河村の孫にあたる ことから、河村と正教会聖堂建築に関する資料を収集整理されてい た。一部成果を発表されただけで20)、2002年急逝され、日本建築界 及び日本ハリストス正教会にとって誠に残念なことであった。本調 查にあたり、遺族から快く内井昭蔵氏収集の資料を拝見させていた だいた。

河村伊蔵は、慶応元 (1866) 年11月に知多半島の内海に生まれた。 内海は伊勢湾と江戸を結ぶ廻船問屋が拠点にしていたところで、明 治中期まで港町として大いに栄えていた。明治16 (1883) 年、河村が 17歳の時、半田教会で同村同年代の青年たち数名と正教会に入信し ${ }^{21)} 、 3$ 年後の明治 19 (1886) 年、東京本会付属の神学校に入学した。卒 業すると聖職に就き、そこで詠歌隊を勤めていた函館出身の信徒 「栄(えい)」と結婚した。東京聖堂の副輔祭から始まり、大正 4 (1915) 年頃に輔祭、昭和8 (1933) 年に長輔祭、1937年には司祭を叙聖 され、昭和 15 (1940) 年 2 月 5 日に 75 歳で亡くなった。日露戦争以後、 ニコライとセルギイの 2 人の主教の下で施設営縡を担ったが、どの ようにして設計を学習し、さらにこれらの聖堂を設計、建設して いったのかは明らかではない。大きな理由は、前述したように各教 会の設計図、写真、教会日誌、信者の記録といった資料が戦災のた めに焼失・紛失したことや、信徒が減ってしまいそれらが受け継が れなかったためである。例外的に、豊橋教会の場合、設計図面や教 会日誌などが今日まで継承され、これらを通して建設経緯を整理す る。

\section{4. 豊橋聖堂建設の経結}

豊橋では、明治12 (1879) 年に中八丁に初めて礼拝堂が設けられ、 昇天教会と名付けられた。木造総二階建てで、一階は信徒集会所、 二階が礼拝所の典型的な明治初期の教会であった。これが信者の増 加とともに手狭になり、明治37 (1904) 年に第十八連隊駐屯地の南側 に土地を取得し、ここに新会堂を建設することにした 222 。日露戦争 勃発のため一次中断したが、明治43(1910) 年7月、大阪聖堂が完成す ると、豊橋聖堂の建設熱が再燃していった。明治44(1911) 年 12 月 20 日に「夜7時総会あり。聖堂建築につき種々協議あり。（中略）調査 委員をあげ、調査をなして総会をひらきて報告、協議する」とあ り、建設に向けて大きく動き出すことになった ${ }^{23)}$ 。明治25(1912) 年1 月22日には、「寄付金調查委員より寄付金高の報告あり。寄付金予 算予定額に充ちたるにより、いよいよ建築すること確めら」れ、建 設費の目処もたつた ${ }^{24)}$ 。数年前に竣工した松山と大阪の両聖堂の建 設資金が外部から寄付されたのとは異なり、豊橋聖堂の場合、信徒 自ら建設に必要な費用を寄付したことは特筆すべきことである。

同年1月 31 日、ニコライから聖堂建設の願いが承認されたが、2月 16日に大主教が死去し、事業の開始は5月にずれ込むことになった。 同年5月14日、「東京より河村副輔祭及尾林請負師来豊。ともに正午 
より聖堂建築につき相談す」25) とあり、規模、設計、構造、工期な どについて話し合いが行われたようだ。8月と11月にも設計の打合せ と作図に来ており、補助をしていた地元信徒の大川氏はその時の様 子を「東京本会より河村副輔祭がこられ、泊まりこみで建築製図を 引いておられた。私も時々その室に出向き、かたわらから文マワシ (コンパス)をいたずらした記憶がある」26) と書き記しており、河村 が設計図面をひいたことは間違いない。

ニコライは、これまで地方の聖堂建設に際して、自ら設計案を指 示していたが、豊橋聖堂の場合、ニコライはその建設を承認すると ともに亡くなってしまった。後を任された河村は、自分の判断で設 計を決めなければならなかったと考えられるが、それについては後 半で検討する。約 4 ケ月後の 10 月末に、県への建築許可申請用の図面 が完成し、そして豊橋の信徒代表の名前で県に建築許可を申請し、 明治 $25(1912)$ 年11月 25 日に認可が下りた 27$)$ 今回公開された図面 は、後述するように工事用図面 (いわゆる施工図)に近く、県への許 可申請のための図面とは異なり、河村は聖堂の実施設計を引き続き 行っていたと考えられる。豊橋聖堂の設計について、残された設計 図面から分析する。

\section{5. 設計の手順と特徴}

信徒の方が保管していた建築図面は20枚あり、杉板で作られた木 箱に 4 巻きに分けられて丸められて納められていた。木箱の蓋の表 には、「聖使徒福音者馬太聖堂設計図 豊橋昇天教会」、蓋の裏に は、「大正四年二月三日新調」と、いずれも墨で記されている。こ れらの建築図面はその由緒とともに、実際に現存する聖堂の形態と 一致するため、豊橋聖堂のものであることは間違いない。また、木 箱の蓋裏に記された「大正四年二月三日」の日付は、同年2月7日の 成聖式 ${ }^{28)}$ に合わせて、図面類を納めるこの容器が用意されたことを 示している。

写真資料は、土台石を据え付けている途中の写真1枚、上棟式と考 えられる写真1枚、仮障壁を使った成聖式の写真1枚、の合計3枚であ る。このうち、上棟式と考えられる写真は、『豊橋八リストス正教 会100周年記念誌』にすでに掲載されているが、他の2枚はこれまで 未公開のものである。これらは、次項で述べるように施工過程から 完成直後の姿を知る上で貴重な資料である。

表1 木箱に収められていた図面一覧

\begin{tabular}{|c|c|c|c|c|}
\hline 巻物仮番号 & 図面番号 & 表題 & 縮尺 & 図面寸法(縦x横) \\
\hline \multirow[t]{8}{*}{ 巻物 1} & 第壱号 & 表題なし(平面図基礎図) & 20分の1 & $1467 \mathrm{~mm} \times 556 \mathrm{~mm}$ \\
\hline & 第武号 & 鐘楼側面全図 & 10分の1 & $2296 \mathrm{~mm} \times 798 \mathrm{~mm}$ \\
\hline & 第参号 & 本堂側面外部 & 10分の1 & $2100 \mathrm{~mm} \times 800 \mathrm{~mm}$ \\
\hline & 第七号 & 鐘楼下部階段卜二階根太 & 10分の1 & $546 \mathrm{~mm} \times 508 \mathrm{~mm}$ \\
\hline & 第八号 & 鐘楼二階々段 & 10分の1 & $508 \mathrm{~mm} \times 585 \mathrm{~mm}$ \\
\hline & 第九号 & 鐘堂小屋組之図 & 10分の1 & $524 \mathrm{~mm} \times 507 \mathrm{~mm}$ \\
\hline & 第拾号 & 鐘堂床組之図 & 10分の1 & $508 \mathrm{~mm} \times 515 \mathrm{~mm}$ \\
\hline & 第十一号 & 渡家側面外部 & 10分の1 & $1118 \mathrm{~mm} \times 800 \mathrm{~mm}$ \\
\hline \multirow[t]{4}{*}{ 巻物 2} & 第四号 & 鐘楼骨組卜渡家取付 & 10分の1 & $1825 \mathrm{~mm} \times 917 \mathrm{~mm}$ \\
\hline & 第五号 & 本堂卜至聖所取付 & 10分の1 & $1045 \mathrm{~mm} \times 919 \mathrm{~mm}$ \\
\hline & 第六号 & 本堂卜渡家取付 & 10分の1 & $915 \mathrm{~mm} \times 860 \mathrm{~mm}$ \\
\hline & 第七号 & 本堂側面ノ半分 & 10分の1 & $965 \mathrm{~mm} \times 915 \mathrm{~mm}$ \\
\hline \multirow[t]{6}{*}{ 巻物 3} & (番号なし) & 表題なし(門の平面・立面図) & 50分の1 & $331 \mathrm{~mm} \times 584 \mathrm{~mm}$ \\
\hline & (番号なし) & 表題なし(門扉上部飾り) & 未記入 & $396 \mathrm{~mm} \times 322 \mathrm{~mm}$ \\
\hline & （番号なし & 表題なし(司祭館平面図) & 20分の1 & $588 \mathrm{~mm} \times 358 \mathrm{~mm}$ \\
\hline & (番号なし) & 表題なし(門扉上部十字架) & 未記入 & $395 \mathrm{~mm} \times 325 \mathrm{~mm}$ \\
\hline & (番号なし) & 表題なL(門柱据付図) & 未記入 & $940 \mathrm{~mm} \times 585 \mathrm{~mm}$ \\
\hline & （番号なし & 表題なし(アーチと箱の図) & 未記入 & $787 \mathrm{~mm} \times 365 \mathrm{~mm}$ \\
\hline \multirow[t]{2}{*}{ 巻物 4} & (番号なし) & 表題なし(聖堂南立面図) & 未記入 & $488 \mathrm{~mm} \times 642 \mathrm{~mm}$ \\
\hline & (番号なし) & 豊橋ハリストス正教会平面図 & 100分の1 & $513 \mathrm{~mm} \times 800 \mathrm{~mm}$ \\
\hline
\end{tabular}

図面 (表1)は 4 巻からなり、巻物1には第壱号、第武号、第参号、 第七号、第八号、第九号、第拾号、第十一号と、通し番号が付され た8枚の図面があり、平面図、立面図、伏図に分けることができる。 巻物 2 は軸組矩形図であり、第四号、第五号、第六号が取合い部分 を描いているのに対して、第七号は聖堂側面のものである。これら 巻物 1 と 2 の図面は、聖堂本体の工事のために必要な図面であり、当 初、巻物 1 の第参号と七号の間に巻物 2 の軸組矩形図3枚を挿入し、平 面図、立面図、矩形図、伏図と一揃えにするはずだったと思われ る。そして、取合い軸組矩形図に3枚分を確保しておけば十分と思っ ていたが、本堂側面軸組を説明する必要が生じ、そのために第七号 が後から加えられたのであろう。また、巻物 1 の最後に立面図の第十 一号が配置されたのも、後から作成されたためであると考えられ る。巻物 3 は外構・金物等の工事のための9枚の図面であり、こちら には番号は付されていない。この図面は、聖堂本体の建設に直接関 係しないので、ここでは言及しない。巻物4には構内建物青焼図面と スケッチのような側面図が束ねられ、これらは描き方から判断し

て、聖堂設計の図面ではないと考えられる。

\section{$5-1$. 平面}

第壹号(巻物1) (図1)は、図面表題は記されていないが、ポーチか ら至聖所に至る軸線から南側部分の平面とその土台石積の側面が描 かれている。図面には、部分名称とその寸法・仕様が描かれておら ず、各部の位置関係を示す施工図に近い。各部寸法・仕様がないの は、別に仕様書が作成されていたと思われるが、今回は発見されな かった。建物の寸法は軸組中心線から計測され、建物全体の東西方 向の長さは、この図面脇に墨書きされているように「総計八拾尺」 である。西側から、幅 8 尺 $\times$ 奥行 7 尺のポーチ、12尺 $\times 12$ 尺の玄関、 18 尺 $\times 18$ 尺の啓蒙所、 30 尺 $\times 30$ 尺の聖堂、そして 24 尺 $\times 13$ 尺の至聖

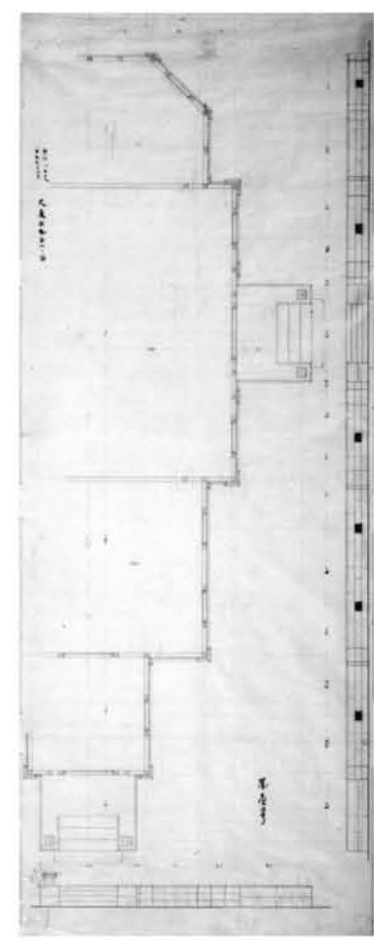

図1 第壱号·平面図基礎図

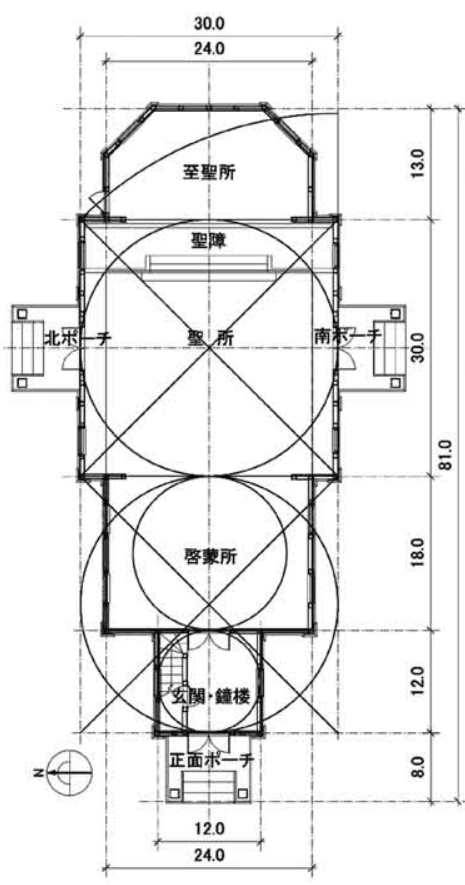

図2 豊橋聖堂平面(実測による) 

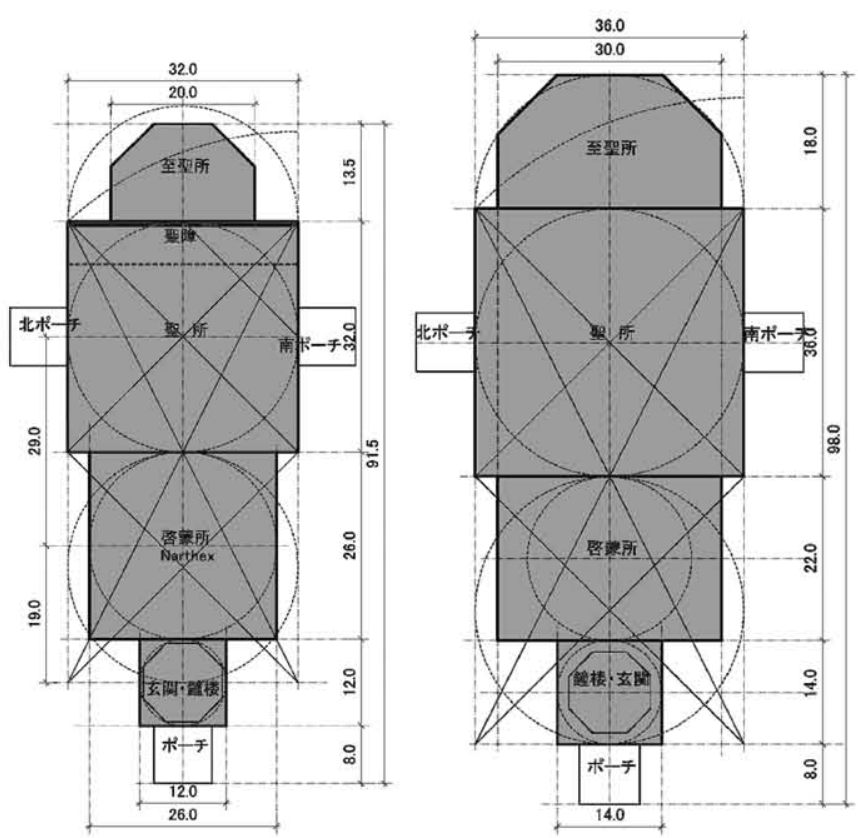

図3 京都聖堂平面(記念誌による)

図4 大阪聖堂平面 (記念誌による)

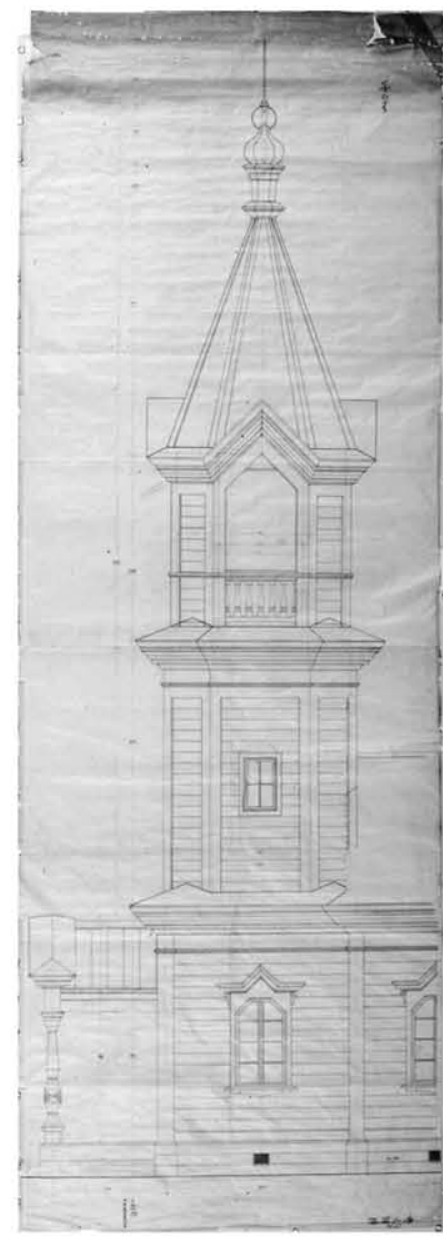

図5 第式号·鐘楼側面全図

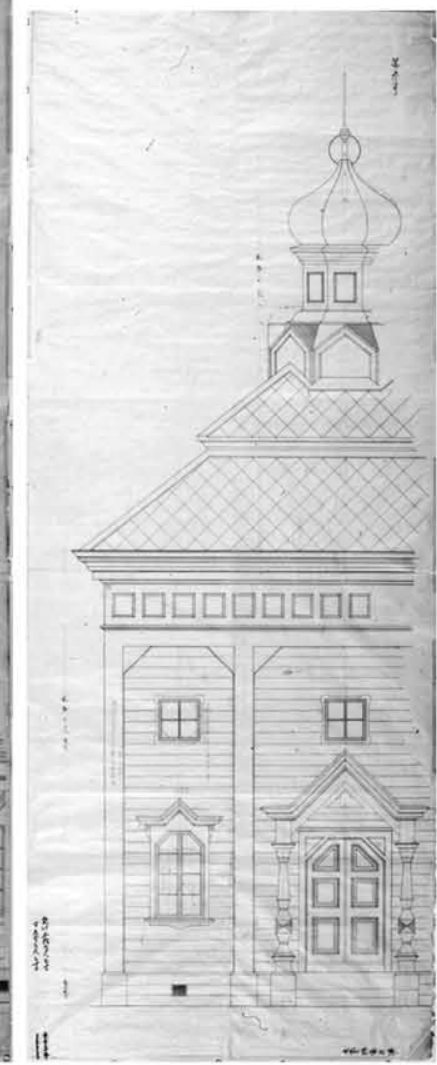

図6 第参号·本堂側面外図

所が東方向に一直線に並ぶ。

基礎石積には柱形と換気口が設けられているが、地面下部分が描 かれておらず、「土台下コンクリート」29)などについて仕様書に特
記されていたのであろう。ほかに、図面の脇に青鉛筆で「尺二改 ム」と記されているが、これは日本の尺寸ではない寸法を尺寸に換 算したか、なんらかの比率にもとづいて計算された尺寸に小数点端 数がでたため、それを尺寸整数に丸めたとも考えられる(図2)。

さて、この平面はどのようにして決められたのであろうか。河村 は、設計期間中に豊橋から数回京都と大阪にでかけており、これら の聖堂を参考にするためであったと考えられる。まず、全体配置 は、西からポーチ、鐘楼付玄関、啓蒙所、聖所、至聖所と東方に一 直線に並び、西から徐々に横幅が拡大し、至聖所ですぼむ。現状の ポーチと至聖所は、敷地境界線と最小限の間隔しか空いておらず、 この用地に建つ建物では東西方向に 80 尺ほどの有効長しかとれな かったことがわかる。京都聖堂(図3)の総長が91.5尺、大阪聖堂 (図 4)が98尺であるのに比べると豊橋聖堂が一回り小さいのは、敷地条 件によるものであると考えられる。

これら三つの聖堂を全体規模から比較検討寸ると、豊橋聖堂は潤 沢な寄付金で大きく作られた大阪聖堂よりも京都聖堂の方に近い が、各部の比率では大阪聖堂とほぼ同じである。大阪聖堂の聖所幅 36 尺を30尺に縮め、他の各部寸法をそれにならい6分の5にすると、 啓蒙所が22尺から18尺に、玄関が14尺から12尺になり、豊橋聖堂と ほぼ重なるのである。正面のポーチは8尺から7尺へ、奥の至聖所は 18尺から13尺へと、この比率以上に縮小され、最後の調整がここで 行われたと考えられる。また、四角形空間が軸線対称に並ぶことが 分かっているので、平面全体を描く必要はなかったのであろう。

\section{$5-2$. 立面}

第式号「鐘楼側面全図」(巻物1)（図5)は、鐘楼と玄関の南立面を 描いた図面である。外壁は下見板張の表現で現状と同じだが、1階の 空は両開き空、2階は填め殺し空として描かれており、現状の上げ下 げ空とは異なっている。図面上の空の周囲には青鉛筆で加筆されて おり、これが修正の指示であったと考えられる。図面には、赤で高 さ方向と水平方向の寸法線が記入され、高さ方向は、地面から1階軒 まで17.2尺、1階軒から2階軒まで16.65尺、2階軒から3階軒まで 11.95尺、3階軒から屋根頂部下端まで15.7 尺、屋根頂部下端から屋 根飾り下端まで 2.55 尺、屋根飾り下端から上端まで 3.85 尺、避雷針 長さ 4 尺である。図面下端に「高専総計六拾七尺四寸」と墨書きされ ているが、避雷針長を除いてこれらを合計すると実際は 67.9 尺にな る。また、水平方向は、1階部分 (玄関) の奥行 (東西方向) が 12 尺、 2 階部分の東西方向幅が11.3尺、2階の八角形平面の一辺が5.7尺、3階 の東西方向幅が 10.6 尺、3階の八角形平面の一辺が 5.4 尺、3階開口内 法が4. 1 尺となっている。なお、鐘楼3階軒裏の部分に鉛筆で「此処 ヨ四寸位トシテ空気抜习付ケル事」と書かれており、設計当初には なかった空気抜けの設置を指示している。

第参号「本堂側面外部」(巻物1) (図6) は、聖所の北側または南側 の外観の左半分を描いたものである。外壁は下見板張りの表現で現 状と同じだが、屋根にペディメントが無いこと、軒下の飾りがある こと、聖所下方の空が両開き空になっていること、聖所上方の小空 が正方形になっていること、が現状と大きく異なっている。随所に 鉛筆書きで修正されており、聖所下方の空は上下空に修正され、

「下八武枚上下ゲノ事」、「空ヨ七分上ゲル」とされている。ま た、聖所上方の正方形小空も角を切るように鉛筆描きで修正され、 


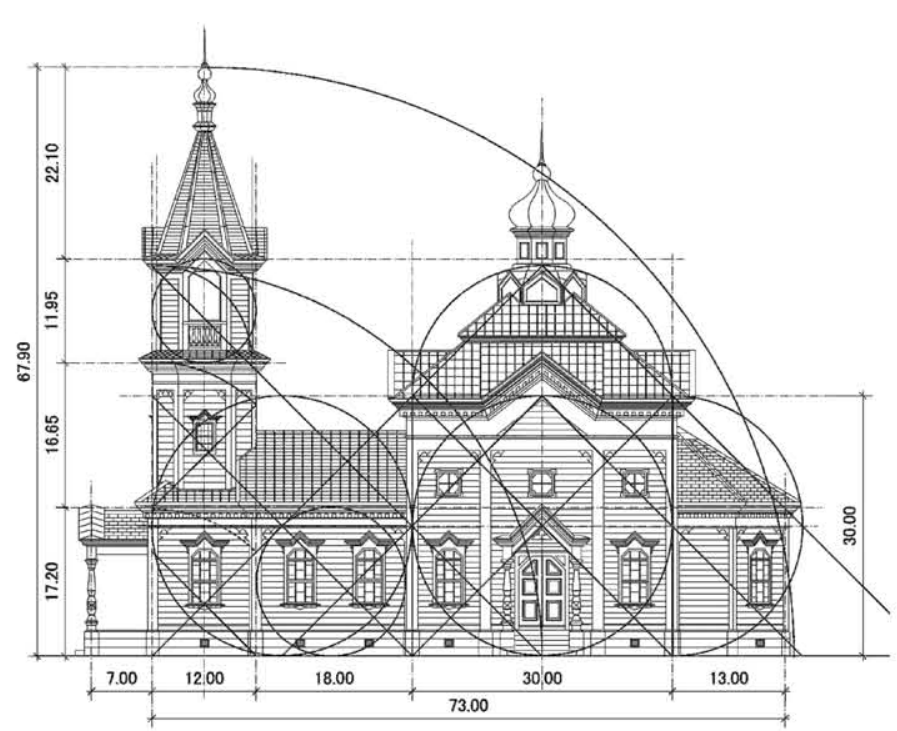

図7 豊橋聖堂側面の構成と各部の比率

「此空八内部蛇腹ノ都合二テ外部ノ中央二置ク」とされ、この空の 位置を上げている。さらに、キューポラ露盤の足元には「此処习四 寸縮ムル事」と鉛筆書きされ、高さを下げている。

図面には赤で高さ方向の寸法線が記入されている。高さ方向の寸 法は、基䃈が 2.2 尺、基礎上端から屋根軒先まで 27.1 尺、屋根下端か ら飾り上端まで 27 尺、と記入されて、図面には「総計五拾七尺三 寸」と墨書きされているが、実際の合計は56尺3寸であり、1尺異 なっている。外壁隅の定規柱に「定木柱壹寸二分厚角八実入箱付」 と鉛筆書きされており、下見板の隅を押さえる定規柱の厚さと隅の 接合を指示している。

第十一号「渡家側面外部」（巻物2）は、啓蒙所（渡家）北立面図 であり、その小屋組も朱書きで描き加えられている。すでに、第式 号において鐘楼側面とともに啓蒙所側面が描かれ、施工のためには それで十分であったはずである。この図面が描かれた目的は、啓蒙 所の外観と構造を確認することと、軒裏に「此処 抜キヨ付ケル事」と鉛筆書きがあるように、軒裏の換気口設置を後 に示すことにあったと考えられる。表題は裏側に墨書きしてある が、図面番号は鉛筆書きであり、後で描き加えられた図面であると 考えられる。

4枚の立面図を見比べると、鐘楼付玄関の外観寸法に微妙な数值が 与えられており、その大きさを決めるのに河村は大きな苦心をした ことがうかがえる。その1階軒高と2階軒高はともに17尺前後の数值 になっており、これは何を意味するのであろうか。前述したよう に、河村はコンパスを片手に製図板に向かっていたというのである から、17尺という高さは12尺方形玄関の対角線長からとったと考え られる。さらに、その 2 階平面の縮小に合わせて、2階高も若干低く している。3階の軒高は人が立って鐘を突く必要から11尺ほどとし、 すると地面からの合計が45尺前後となる。45尺という寸法は、聖所 では地面からキューポラ露盤上までの高さにあたり、そうすると聖 堂側面各部は円と対角線の交点に位置することがわかる(図7)。鐘楼 のキューポラ頂部までの高さを半径とする円弧は、聖所キューポラ 頂部を通り、至聖の外壁の位置に重なる。側面図にある修正書き

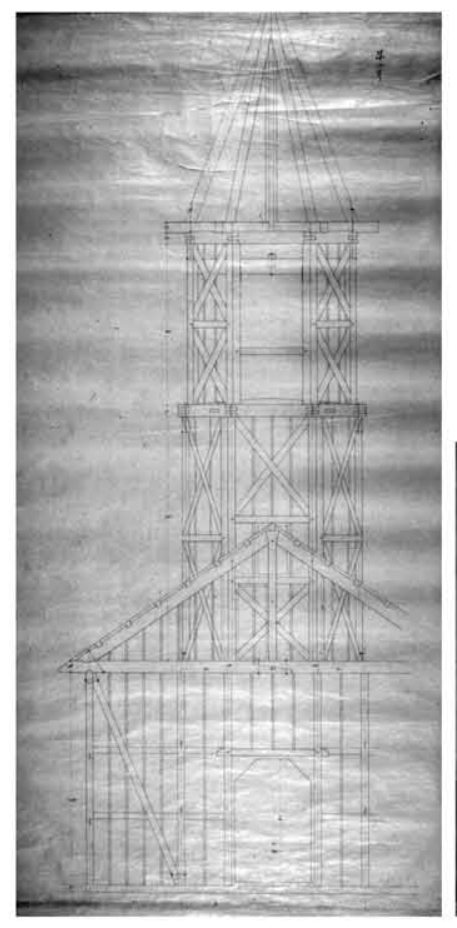

図8 第四号·鐘楼骨組卜渡家取付

図9 第五号·本堂卜至聖所取付

は、河村が「文マワシ」によって全体の比率構成を考え、実際の施 エに合わせて各部の寸法を調整した証といえる。

\section{$5-3$. 軸組}

第四号「鐘楼骨組卜渡家取付」(巻物2)(図8)は、啓蒙所の壁を含 む鐘楼の軸組矩形図である。図面には各部材の寸法と配置が書かれ ており、注目すべきは1階東面中央の柱間隔 5.85 尺が鐘楼2階東面で 5.11尺と狭められ、柱の位置をそれぞれ0.37尺内側に入れるように 指示されていることである。同様に、鐘楼2階北面、南面の柱も玄関 の北面・南面の柱より 0.35 尺、さらに鐘楼 3 階の柱はいずれも 2 階の 柱より内側に0. 35尺内側に入れるように指示されている。これに よって、鐘楼は、1階から3階に向かって外壁も 0.35 尺ずつ内側にす ぼみ、鐘楼の平面は上階に向かって莪減していくこととなる。その ため、鐘楼には通柱はない。また、図面で目につくのは、補強のた めの筋違と金物が多用されていることであり、濃尾地震以後に木造 建築に施された典型的な耐震補強である ${ }^{30)}$ 。

上階にいくに従って狭まってゆく塔は、仏塔を見慣れた日本人に とって馴染み深い。しかしながら、京都聖堂では鐘楼の隅切りが上 にゆくに従って若干大きくなるだけで、鐘楼平面自体は縮小して いっていない。また、大阪聖堂では玄関を方形のまま2階軒の高さま で延ばし、そこに唐突に八角形の鐘堂を載っけている。こうする と、別個の構造体が二段に重なっているだけで、派減する塔のイメ ージから遠くなる。このように豊橋聖堂の鐘楼には河村の創意が見 られるが、京都聖堂、函館聖堂、白河聖堂などと比較すると、より 河村の設計手法が明らかになると思われ、次稿の課題としたい。

第五号「本堂卜至聖所取付」(巻物2) (図9)は、聖所（本堂）と至 聖所の間の壁を聖所側から見た軸組図である。奥に至聖所の屋根も 描かれている。聖所の軒桁繋ぎ部分は、上下に鉄プレートを当てて ボルト締めとされている。また、聖所1階の壁には筋違が配され、柱 


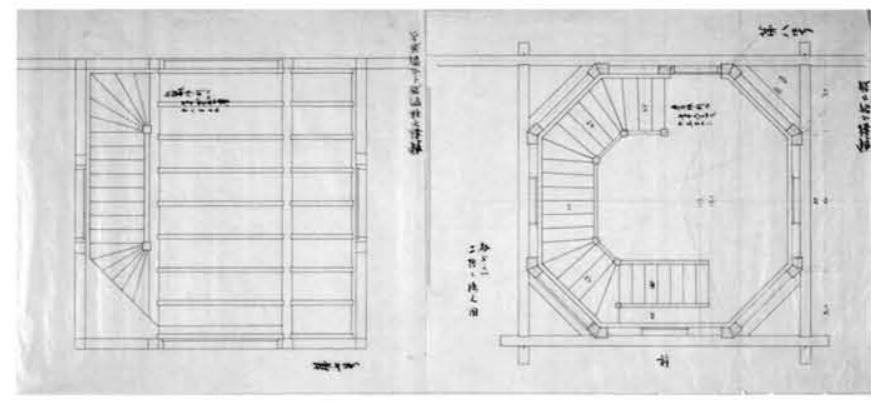

図10 第七号·鐘楼下部階段卜二階根太 図11 第八号·鐘楼二階段々

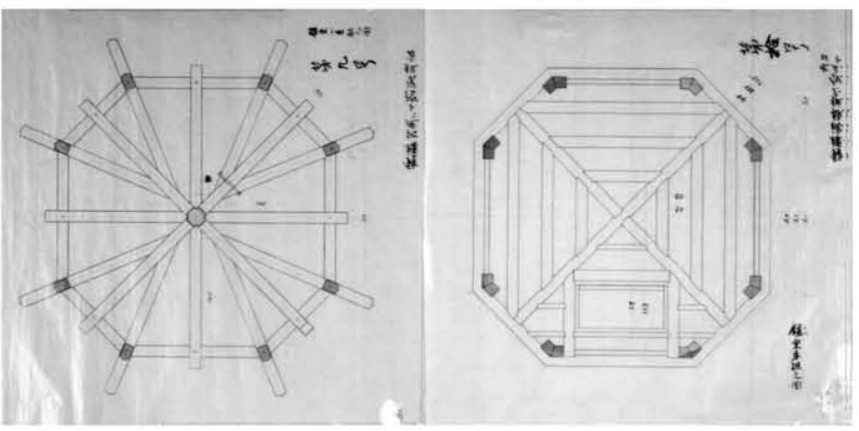

図12 第九号·鐘堂小屋組之図

図13 第拾号·鐘堂床組之図

との接合部もまたボルトで固定されている。

第六号「本堂卜渡家取付」(巻物2) は、聖所 (本堂) と啓蒙所 (渡家) の間の壁の軸組図であり、啓蒙所側から見た図面である。聖所と啓 蒙所とを仕切る壁には筋違が入り、聖所の軒桁と間柱は「羽子板」 ボルトで固定されている。聖所の軒桁繋ぎ部分は、第五号図面(図9) に描かれた至聖所側の軒桁と同様に、上下に鉄プレートを当てボル 卜締めされ、筋違と柱・胴差もまたボルト締めされている。

第七号「本堂側面ノ半分」(巻物2) は、聖堂 (本堂) 側面の軸組図で ある。筋違と柱・軒桁、筋違と柱・胴差の結合部はボルト締めで 固 定され、軒桁の繋ぎ部分は、鉄プレートを桁に当ててボルト締めさ れている。

第七号「鐘楼下部階段卜二階根太」(巻物1) (図10)は、鐘楼の1階 から2階に上がる階段と2階床を支える根太を描いた伏図である。階 段には「武拾壱段二割ル」、蹴上「高市六寸二分」、踏面「巾六寸 五分」と墨書きされている。

第八号「鐘楼二階々段」(巻物1) (図11) は、鐘楼の2階平面図であ り、これから鐘楼2階が正八角形ではないことがわかる。もともと正 八角形を作ろうとしたのではなく、正方形に組まれた1階軒桁の四隅 に火棺梁を掛け渡し、その上に八角柱の鐘楼2階部分を載せようとし た。火棺梁上の側面が東西南北のそれよりも狭くなったのは、1階か ら上がってくる階段幅に合わせて2階床大引を配置したためであると 考えられる。第 2 に注目すべき点は、鈍角に交わる壁を作り出すた めに、二本の柱を添わせて対応していることである。強度的に有利 であったはずで、鐘堂階もそのようになっている。第 3 の点は、2階

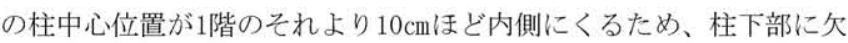
掛きを作り、それを軒桁に掛けていることである。下階の $135 \mathrm{~mm}$ (4寸 5分) 角の柱を軒桁を介して上階で内側にずらす寸法は、柱下部の一 部を軒桁に掛けることを考えると、10cm程度がちようどよかったと
思われる。鐘堂の各柱もまた、「鐘楼骨組卜渡家取付」(図8)を見る と、八角形のリングに組まれた 2 階の桁の内側に一部が掛けられて いる。

第九号「鐘堂小屋組之図」（巻物1）（図12）は、鐘堂の屋根を支え る小屋組を示した図面である。順当であれば、第拾号の鐘堂床組の 方が先番のはずが、何の理由か逆順になった。中心の梁の上に束柱 を立て塔の小屋組を支えている。正八角形でないために、中心から 放射状に梁を柱の上に掛け渡すことができず、それぞれの桁の中央 に載せている。そして、側壁交差の鈍角を二等分する位置に「控 梁」を配置し、その梁との接合部をボルト締めで固定している。図 面背面には「鐘楼地迴リ卜控梁組方」と墨書きされているが、「地 廻リ」とは中心から桁の上に掛け渡された長い梁材を、また「控 梁」は柱の上から梁に掛け渡された短い梁を指しているものと考え られる。

第拾号「鐘堂床組之図」（巻物1）（図-13）は鐘堂の床伏図であ る。2階床伏と同じように、南北方向に大引をかけるだけでもよかっ たはずであるが、ここでは短辺側壁の軒桁にX形に梁を架けてい る。このようにしたのは出入口の位置の都合からというより、鐘楼 の剛性を高める目的からと考えられる。図面の裏面には、「鐘楼濡 縁根太組立卜出口」と記されている。

以上、これら12枚の図面は、第壹号の縮尺が20分の1であるほか は、すべての図面の縮尺が10分の1であること、また、柱、基礎、土 台、軸組、小屋組、鐘楼の階段や床などの詳細が描かれているとい う図面の内容から判断して、実際の施工を行うための図面であると 考えられる。

\section{5-4. 立面スケッチ(図14)}

巻物 4 の立面スケッチであるが、今回発見された図面集の中で唯 一ケント紙に墨入れ描きされている。豊橋聖堂と比較すると、聖所 と玄関に比して啓蒙所が長く、また外壁の仕上げ、開口部の位置と 大きさ、屋根の形態、細部などが異なり、京都聖堂により近い印象 を受ける。また、聖所と鐘楼が左右対称に描かれておらず、画法に 稚拙さも見受けられ、設計の素人の手になるものと考えられる。す ると、これはニコライがロシアから持ってきた参考図譜集の一枚で ある可能性が高く、京都聖堂の実施設計を担った松室重光はこの図

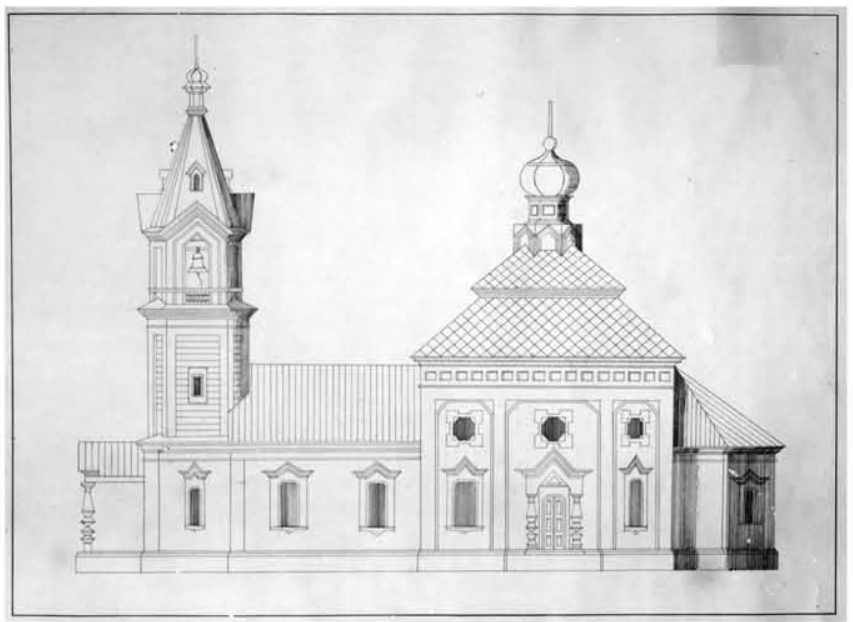

図14 巻物 4 の南立面スケッチ（図面名称なし） 
に割合忠実に従い、一方、大阪聖堂と豊橋聖堂では河村はこれに改 良を加えて、実施設計を作成したのではないだろうか。すなわち、 ニコライから提供された同じ一つの参考図をもとに、京都、大阪、 豊橋の聖堂は実施設計されと想像され、これは次稿の研究とする。

\section{6. 施工過程}

河村は設計図を完成させると、大正元 (1912) 年11月 29 日から 12 月 3 日の間に大工、石工、屋根、䔍、左官などとの契約を済ませ、施工 の準備を完了した ${ }^{31}$ 。教会誌にはその間の河村の活動が記述されて おり(表2)から、その記録と今回公開された写真から施工の手順と完 成直後の様子を分析する。

表2 河村の施工期の豊橋滞在と工事内容

\begin{tabular}{|c|c|}
\hline 大正2(1913)年の滞在期間 & 工事状況 \\
\hline 1月 15 日 2月11日(28日間) & 地業工事、基礎工事(石工事) \\
\hline $\begin{array}{l}\text { 2月 } 25 \text { 日〜 4月 } 12 \text { 日 } \\
\text { (短期出張を除き延 } 44 \text { 日間) }\end{array}$ & 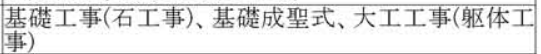 \\
\hline 6月 17 日 7月7日( 22 日間) & 書工工事(外壁及び仕上げ工事)、屋根板金工事 \\
\hline 7月26日～8月21日(27日間) & 大工工事(外壁及び仕上げ工事)、屋根板金工事 \\
\hline
\end{tabular}

\section{6-1. 基礎工事(写真1)}

教会誌によれば、大正元 (1912) 年12月10日に縄張りを行い、厳冬 下の12月に掘削、丁張撕け、そして千本突きのうえ「土台下コンク リート打ち」が始まった。翌年、1月21日に打設を終え、2月2日から は土台石の据え付けが始まり、2月27日に基礎成聖式を迎えた。教会 誌には、「聖堂基礎式ノ際、東南隅ノ二段目ノ土台石ノ中二入レシ、 記念記録写し」32) と書き記されているので、写真1はそれ以前に 写されたものである。この写真から、「土台下コンクリート」打設 は啓蒙所南側から始まり、聖所、至聖所と反時計周りに進み、それ 追うように石積み行われたことがわかる。また、玄関周りと聖所・啓 蒙所北側の土台位置には筵のようなものが敷かれ、コンクリートを 養生してるるのが確認できる。この「土台下コンクリート」は捨て コンクリート程度のものではなく、土台石据付用のフーチングで あった可能性もある。

聖所中央部と至聖所中央部に立てられた棒は、縄張りの際に聖堂 の全体位置を確定するために使われたと考えられる。教会誌によれ ば、基礎工事は4月初旬に完了したことになっている。

\section{6-2. 上棟式(写真2)}

基砒工事が進む中、河村は豊橋を拠点に数度にわたり京都と大阪 にでかけており、おそらく、細部に関しても両聖堂を参考にしたと 考えられる。3月12日、大工による木取が始まり、木工事は順調に進 んだらしく、3 ケ月後の6月 3 日に「棟上げ。午前拾時、影田神父の 為めパニヒダ執行。重なる人々多数参拝あり。夜、棟上げの祝ひを 教会に於て催し」 ${ }^{33)}$ 、棟上式が挙行された。この写真は敷地の南東 側から聖堂を写したもので、聖堂の柱・梁など軸組と小屋組がすべ て完成した状態になっている。そして、数名の信徒らしき人物が子 供とともに建物手前に並び、また神䌅を着た多数の職人が小屋や足 場に立って写真正面を向いて写っていることから、棟上式の写真で あることは間違いない。

この写真から分かることは、第一は木工事を担った大工が、袢縉 の文字から「中神」という屋号を持った大工であったことである。
第 2 は、図面には描かれていなかった軸組詳細が見えており、聖所 の小屋組は陸梁を用いず四本の隅木を中央でもたれ合うように接合 して作り出され、四周に配された梁・桁には火槌梁で架けて補強 し、この内側に八角形ドーム型天井をおさめていることである。第 3 は一連の設計図面との相違で、聖所南側空の位置の変更と、それ

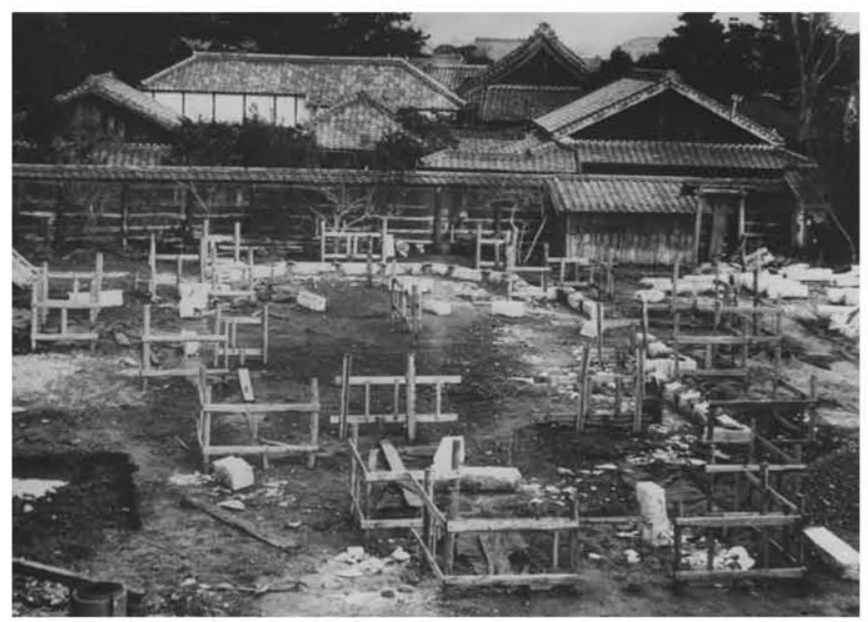

写真1 基礎工事の様子

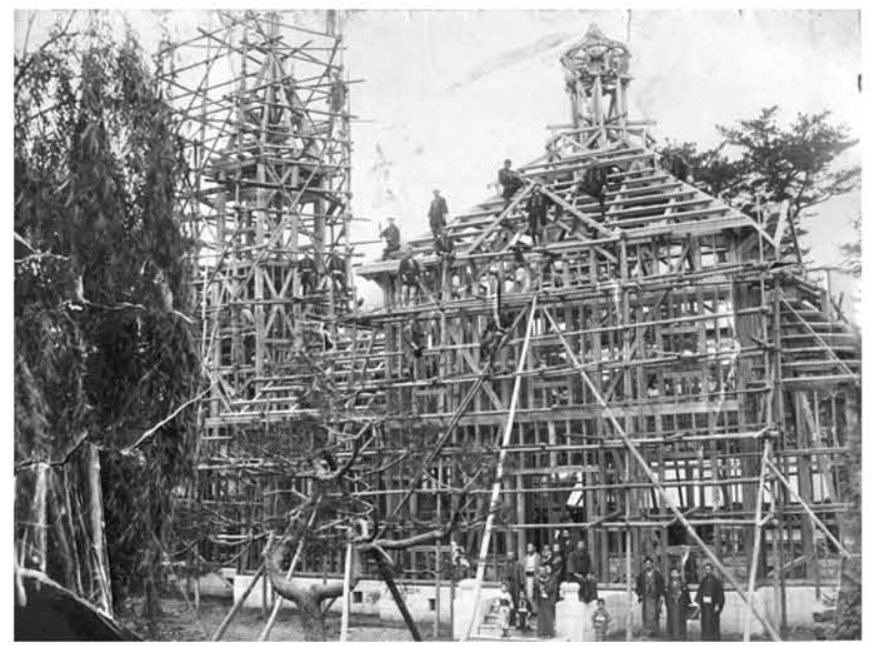

写真2 上棟式の様子

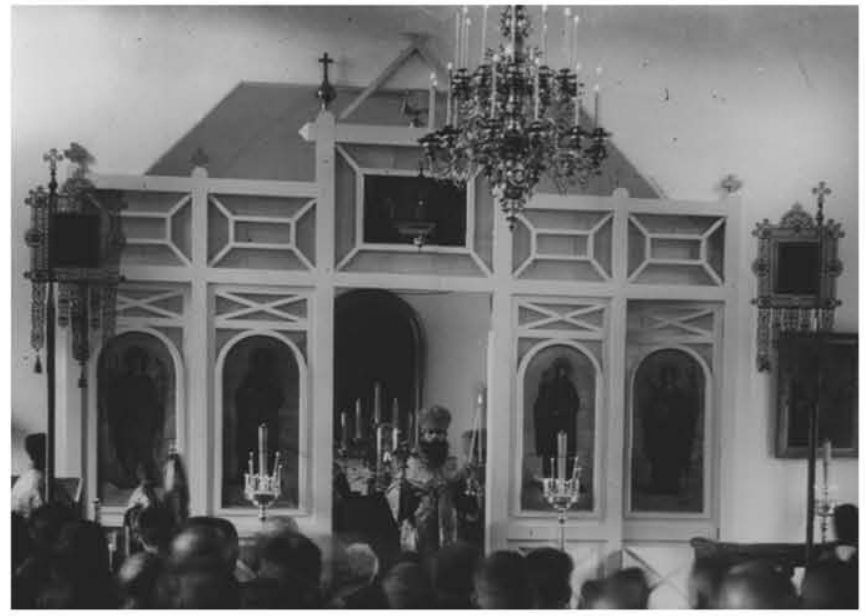

写真3 仮聖障による成聖式 
に伴う構造部材の変更である。図面では、聖所南側の上部の空はそ の下端を胴差上端に合わせているが、これは設計途中で変更され、 空の位置が上方にずらした。写真はそれを示しており、これによっ て、図面では空上端の位置に胴貫が通されていたが、それがなく なった。

\section{6-3. 成聖式の写真 (写真3)}

教会誌によれば、大正4 (1915) 年2月7日、東京からセルギイ主教を 招いて成聖式を行ったことになっており ${ }^{34)}$ 、写真3はその時の様子を 写したものである。ここで注目すべき点は、写真の背景の聖障で、 現存する聖堂のものとは異なっていることと、聖堂が完成してから 1 年以上経った時期に成聖式がおこなわれたことである。信徒たちが 聖堂建設、外構工事、司祭館建設、聖障と鐘の準備をひとつひとつ 段階的に進め、そのほとんどは河村に任されたが、聖障だけは違っ ていた。

大正3 (1914) 年2月9日、豊橋教会男子会を開き、ここで初めてイコ ノスタス (聖障)の入手方法について話し合いがおこなわれた ${ }^{35) 。 そ ~}$ の後、同11日には、河村を通さず、建設委員会はセルギイ主教より 送られてきた聖障図面を検討し、その結果を本会に伝えた ${ }^{36)}$ 。最終 的に、聖障はロシアに発注されたが、なかなか届かず、同年9月 24 日、「仮障壁をもって成聖式」をおこなうことを決め、セルギイ主 教にその承認を求めた ${ }^{37)}$ 。

これは許可され、豊橋教会は、12月13日に河村に仮聖障の取り付 けと成聖式の準備を本会に依頼し ${ }^{38)}$ 、年が明けた大正 4 (1915) 年1月 に河村が来豊し、仮障壁の設計と施工指揮をおこなった ${ }^{39}$ 。ここの仮 障壁を用いて、同年2月7日、成聖式がおこなわれた。この仮聖障 は、昭和2 (1927) 年に現聖障に取り替えられたが、それがロシアに発 注したものであるか不明である。鐘の方は国内では製造依頼せず、 大正3 (1914) 年早々に河村がそれを求めて樺太に出向き、うまく入手 に成功しらしく、同年6月に豊橋に到着している40)。

\section{7. 結論}

以上、豊橋聖堂の建設経緯と設計の特徵をまとめると以下の通り である。

1）聖堂の実施設計と施工監理は河村伊蔵が行った。教会誌には、献 身的に河村がその任務を遂行したことが述べられており、また「河 村輔際が、夜遅くまで建築製図をひいておられた」との信者の記録 がある。さらに、今回発見された設計図面は署名はないが、河村伊 蔵の旧蔵資料にある「河村」の署名と図面中の記述の筆跡とが酷似 しており、彼の作成であると判断できる。

2) 河村は、京都聖堂、大阪聖堂、そして図譜(図14)から、ハリスト ス正教会聖堂の構成配置と各部比率を理解し、豊橋聖堂敷地の条件 に合うようにそれを微調整して、実施設計をまとめあげた。大阪聖 堂の平面図をおよそ6分の5に縮小したのが豊橋聖堂である。

3）派減する鐘楼のデザインは、京都聖堂、大阪聖堂、図譜には見ら れないもので、河村の創意が現れている。そのため、通柱をやめざ るをえなかったが、代わりに各階を双柱と金物で補強した。

4）河村は工事期間中毎月一回は施工監理のために来訪し、現場で設 計変更を行った。変更としては、設計図にはなかった聖所屋根の四 方ペディメントが付加され、空が両開きから上げ下げ空に、また基
礎は3段石積み 2.2 尺の高さから $91.5 \mathrm{~cm}$ (約 3 尺)に、さらに、啓蒙所小 屋組のキングポスト・トラスの釣束が省かれ、補強プレートが添え られた。

5）可能な限り軸面を筋違で固め、また梁と桁との接合部を金物で固 定し、入念な補強をおこなった。これらは当時の木造耐震構法を反 映したものであろう。

6）聖所の屋根・天井は、壁の四隅から中心部に向けて山形に隅木を 掛け渡して小屋組とし、そして陸梁を省略することにより聖堂の八 角形ドーム型天井をおさめた。また、屋根の重みで壁頂部に生じる 外向力を、四隅に配置した火桘梁で耐えており、これが八角形ドー ムの短辺を構成している。

7) 聖堂自体は大正 2 (1913) 年12月に竣工し、また外構工事と司祭館 建設は大正3 (1914) 年6月に完了したが、注文した聖障が到着しな かったため、結局大正4 (1915) 年2月7日に仮聖障によって成聖式が行 われた。

今後、豊橋聖堂完成後、河村によって設計された函館聖堂、白河 聖堂、修善寺聖堂などと比較検討することで、より河村の設計の特 徵が明らかになるであろう。また、東京大聖堂と京都聖堂について は『宣教師ニコライの全日記』に多くの記述が見られ、これらの設 計と建設経緯の解明は次稿の課題としたい。

\section{謝辞}

本稿執筆にあたり、日本ハリストス正教会豊橋教会の皆様、故内 井昭蔵氏の御遺族、豊橋市教育委員会から資料の提供や助言を頂い た。ここに記して謝意を申し上げる。

注

1) 愛知県教育委員会 : 愛知県の近代化遺産 (愛知県近代化遺産 (建造物等) 総 合調查報告書)、2005年.

2）豊橋ハリストス正教会聖堂建築調查団：愛知県指定有形文化財 豊橋八リ ストス正教会聖使徒福音者馬太聖堂建築調査報告書、2007年. 本調查は, 泉 田が正教会略史、設計者、設計手法について、西澤が図面・写真資料に基づい て設計・施工について、伊藤が教会日誌に基づいて施工監理について、そ れぞれ分析、執筆した.また、資料収集には西川嘉泰君 (当時豊橋技術科学大 学修士課程)の協力があった.

3）坂田泉：日本におけるハリストス正教会の建築について、日本建築学会論 文報告集、1964年、479頁.

佐藤巧 : 日本八リストス正教会建築断章、宮城の研究第 7 巻、1983年、 354-356頁.

4）鈴木甲子男：日本ハリストス正教会建築、名古屋大学工学研究科修士論 文、1980年. 同論文要旨は、『正教時報』(1982年3月-9月)に「正教会の聖堂

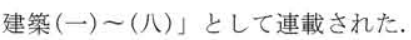

5）文化財建造物保存技術協会編：重要文化財日本ハリストス正教会教団復活 大聖堂 (ニコライ堂) 保存修理工事報告書、1998年.

6）横浜国立大学工学部建築学科建築芸術研究室：日本ハリストス正教会箱根 避暑館小田原ハリストス正教会旧聖堂調査報告、1982年.

7）文化財建造物保存技術協会編 : 重要文化財函館ハリストス正教会復活聖堂 保存修理工事報告書、1989年.

8） ニコライ著·中村雄健之介訳 : 宣教師ニコライの全日記全 9 巻、教文館、 2007 年.

9) Hideo Izumida; 'The Russian Orthodox Churches in Japan,' The Proceeding of the 3rd International Symposium of Architectural Culture of East Asia, Tainan, 2009, pp.188-196.

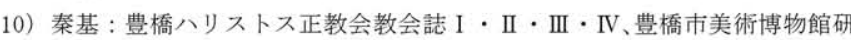


究紀要 $2 \sim 5$ 号、豊橋市美術博物館、1993年-1996年.

11）函館市史編纂室編：函館市史 都市・住文化編、1995年、182-185頁.

12）8）『宣教師ニコライの全日記 $1 』 、 289$ 頁.アナトリイ師から石巻教会の 図面が送られてきたことが述べられている.

佐藤巧 : 旧石巻ハリストス正教会教会堂 宮城の古建築、1983年、127-129頁

13）8）『宣教師ニコライの全日記 $1 』 、 114-128$ 頁. 建築家がレウートフから シチュルーポフヘ、形式がバシリカ式から円形式を経て十字式に変更され た過程が書き記されている.

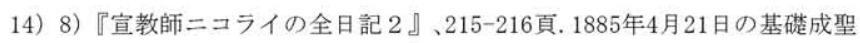
式に引き続き、聖職者集団の育成を検討している.

15）大館拫土資料館『秋田県指定有形文化財北鹿ハリストス正教会聖堂保存 修理報告書』では、大エメシオン貫洞の関与が指摘されている.仙台聖堂に ついては『仙台ハリストス正教会』(69-82頁)に、長郷泰輔がニコライ提供 の図譜を縮小し実施案を作成し、大エワシリイ岡本が施エしたとされてい る.

16）8）『宣教師ニコライの全日記 $6 』 、 149-182$ 頁. 京都聖堂の建築家を松室 に、また施工者を大西に決める経緯などが克明に記されており、京都聖堂の 建設過程については次稿で検討寸る.

水場行楊編：京都至聖生神女福音聖堂の記念画帖、東京聖教本会編集所、 12頁、1904年. 河村が聖器物の設置を担当したことが述べられている.

17）水場行楊編：松山ハリストス復活聖堂、正教会事務所、1911年、9頁.

8）『宣教師ニコライの全日記 $8 』 、 343$ 頁. 河村指揮による松山聖堂建設.

18）水場行楊編：大阪聖堂成聖式記念画帖、東京聖教本会編集所、1911年、

13頁. 8)『宣教師ニコライの全日記 8 (350頁)』には、図鑑19番スケッチを もとに河村が実施設計をすると述べられている.

19）藤森照信 : 近代日本の異色建築家 ロシア正教の司祭として没した河村 伊蔵、科学朝日 1982 年10月号、1982年、97-100頁.

20) 内井昭蔵 : ニコライ堂の思い出、別冊太陽119号、2002年、123-125頁.

21）半田教会メトリカ(宗門帖)による。
慶応元年11月生

尾張知多郡内海村平民川村作平衛長男

モイセイ聖法律者 9月16日 川邨伊蔵 明治17年7月

22）10）「豊橋ハリストス正教会教会誌IV」、78頁. 略記.

23）10）「豊橋ハリストス正教会教会誌IV」、87頁. 建設の決定.

24）10）「豊橋ハリストス正教会教会誌IV」、88頁. 建設費.

25）10）「豊橋ハリストス正教会教会誌IV」、91頁、河村との打合せ.

26）豊橋ハリストス正教会 100 周年記念事業委員会編 : 豊橋ハリストス正教 会100周年記念誌 1875-1979、豊橋ハリストス正教会、1979年、12頁.

27）10）「豊橋ハリストス正教会教会誌IV」、96頁. 建築許可.

28）10）「豊橋ハリストス正教会教会誌IV」、96頁. 成聖式の記述. 豊橋ハリストス正教会 100 周年記念事業委員会編『豊橋ハリストス正教会 100 周年記念誌: 1875-1979 (54頁)』に、成聖式の様子が述べられている.

29）10）「豊橋ハリストス正教会教会誌IV」、77頁.「土台下コンクリート全 部終了」との記述有り.

30）中央防災会議災害教訓の継承に関する専門調查会編：1891年濃尾地震報 告書、中央防災会議、2006年、181-187頁.

31）10）「豊橋ハリストス正教会教会誌IV」、96頁.工事契約.

32）10）「豊橋ハリストス正教会教会誌IV」、77頁. 基礎成聖式の記述.

33）10）「豊橋ハリストス正教会教会誌IV」、81頁. 上棟式.

34）10）「豊橋ハリストス正教会教会誌IV」、96-97頁.成聖式.

35）10）「豊橋ハリストス正教会教会誌IV」、87頁. 聖障の入手の話合い

36）10）「豊橋ハリストス正教会教会誌IV」、87頁. セルギー主教へ手紙

37）10）「豊橋ハリストス正教会教会誌IV」、91頁.仮聖障による仮成聖式

38）10）「豊橋ハリストス正教会教会誌IV」、93頁. 河村の工事

39）10）「豊橋ハリストス正教会教会誌IV」、93頁. 仮成聖式の挙行

40）26）「豊橋ハリストス正教会100周年記念誌：1875-1978、年表.

(2009年10月14日原稿受理， 2010 年 5 月 17 日採用決定） 